\title{
PHYSIOLOGICAL INDEXES OF MINI TOMATO CULTIVARS GROWN IN A PROTECTED ENVIRONMENT
}

\author{
ÍNDICES FISIOLÓGICOS DE CULTIVARES DE MINITOMATES CULTIVADOS EM \\ AMBIENTES PROTEGIDOS
}

\author{
Diego Rangel da Silva GAMA ${ }^{1}$; Kalline Mendes FERREIRA ${ }^{1}$; Vanuza de SOUZA ${ }^{\mathbf{1}}$; \\ Jony Eishi YURI ${ }^{2}$; Alessandro Carlos MESQUITA ${ }^{1}$ \\ 1. Universidade do Estado da Bahia, Campus III, Departamento de Tecnologia e Ciências Sociais, Juazeiro, BA, Brasil. \\ amesquita@uneb.br; 2. Empresa Brasileira de Pesquisa Agropecuária, EMBRAPA- Semiárido, Petrolina, PE, Brasil.
}

\begin{abstract}
Shading screens are widely used to control excessive solar radiation, thereby changing plant growth. Thus, through physiological indices the objective was to evaluate the growth of three cultivars of minitomatoes under colored meshes. The experiment was conducted from April to July in the DTCS / UNEB experimental field in experiment DBC with subdivided plots, and four replicates, comprised of three shaded environments and the control treatment, three cultivars, and seven plant sampling seasons. For growth analysis, we used the destructive method, total dry matter was determined after drying it in an oven at $65^{\circ} \mathrm{C}$. The total leaf area (LAI) was obtained using the software QUANT. Results showed that there was no interaction between environments and the other factors. Regarding leaf area index, cvs. Shani and Sweet Million stood out in all environments, whereas cv. Red Sugar had a similar behavior in all environments. Shani obtained the best indices in open sun environment and in the environment covered with red shading screen, and Sweet Million obtained the best index under gray shading screen. Red Sugar had the lowest LAI, and consequently, the lowest SLA and LAR. On the other hand, it showed the highest RPF, since it obtained the highest dry matter in leaves compared to the other cultivars. Cvs. Shani and Sweet Million showed the best: TAL, TCR, TCA and TCC.
\end{abstract}

KEYWORDS: Shading screens. Leaf area. Growth rate.

\section{INTRODUCTION}

Tomato (Solanum lycopersicum) belongs to the Solanaceae family, and in botanical terms, it is divided into two subgenera according to fruit color. Tomatoes that belong to subgenus Eriopersicon have green, yellow, or whitish fruits; on the other hand, tomatoes belonging to subgenus Eulycopersicon have reddish colored fruits - which is the case of commercially produced tomato (ALVARENGA, 2013). This fresh market tomatois generally consumed in natura and is considered a gourmet product, mainly because it is found in refined dishes and due to its multiple uses.

Tomato is a vegetable with great economic importance in Brazil, which currently ranks the eighth position in terms of global production. It is cultivated in an area of approximately 55.98 thousand hectares, where over 3.86 million tons of tomatoes are produced. In the Northeastern region, tomato cultivation is currently performed basically by small rural farmers, mainly in the states of Pernambuco, Bahia, and Ceará. Due to its traits, it has a great socio-economic importance for the region; Bahia and Pernambuco together are responsible for $50 \%$ of the total Northeastern production, i.e., approximately 294.1 thousand t/year (IBGE, 2019).

The Sub-medium São Francisco River Valley is characterized as greatly suitable for fruit and vegetable production due to irrigated agriculture, and the region has low rainfall and high brightness, climatic conditions that might interfere with yield. In this region, in 2018, 111 ha of tomato were cultivated with a yield of 2687 tons. (IBGE, 2019)

According to Silva et al. (2013) and Rocha et al. (2015), shading screens have been used to minimize the excess of solar radiation and temperature, as they are able, according to Martínez Gutierrez et al. (2016), Buthelezi et al. (2016) and Ilic' and Fallik (2017), to promote light-regulated physiological responses, including gas exchange and chlorophyll content (TAFOYA et al., 2018). Results confirmed by Silva et al. (2013), which reported the interference of shading screens on microclimate and growth characteristics of tomato plants.

There are reports in the literature regarding tomato cultivation in protected environments using white plastic (ROCHA et al., 2015; SILVA et al., 2013; REIS et al. 2012, 2013; HOLCMAN; SENTELHAS, 2012). However, research studies using color or photo-selective screens to evaluate 
Physiological indexes...

tomato growth are scarce (SHAHAK; GUSSAKOVSKY; GAL, 2004; SHAHAK et al., 2008; GAMA et al., 2017).

Dry matter accumulation and increased leaf area, quantified in terms of time, are used in the several ecophysiological studies to estimate several physiological indices regarding differences in performance between cultivars or different materials of the same species and vegetable communities. These indices are typically absolute growth rate, relative growth rate, net assimilation rate, leaf area ratio, and leaf weight ratio, among others (CAIRO; OLIVEIRA; MESQUITA, 2008). It is important to highlight that these evaluations regarding the crop growth under these conditions are not existent for mini tomatoes cultivation.

Therefore, this study aimed to obtain information regarding the performance of three mini tomato cultivars in different types of environments.

\section{MATERIAL AND METHODS}

The presente study was conducted from April to July, 2013, in the experimental field of the State of Bahia, Juazeiro-BA (09 $\left.24^{\circ} \mathrm{S}, 40^{\circ} 26^{\prime} \mathrm{W}\right)$. The climate is semiarid, with mean annual rainfall of $484 \mathrm{~mm}$, and rains are concentrated in the period ranging from November to April.

The analyses were performed by a completely randomized design in a split-split plot system, four replicates comprised of shaded environments (gray shading screens (GS), red shading screens (RS), and blue shading screens (BS)) plus the control treatment, with no shading (OS), three mini-tomato cvs. ("Red Sugar", "Shani", and "Sweet Million"), and seven sampling seasons, which were: $0,15,30,45,60,75$, and 90 days after transplantation (DAT). Plots were comprised of the different shaded environments, split-plots were comprised of cvs., and split- split splot were comprised of sampling seasons. Each plot was comprised of two hundred and forty plants, divided in sub-plots, which were comprised of 80 plants of each cultivar.

For seedling production, it was used polystyrene trays containing 128 cells filled with commercial substrate. To install the experiment, ploughing and seedbed preparation were performed, followed by foundation fertilization (COSTA; FARIA; PEREIRA, 2008), which involves adding fertilizers based on the chemical/physical analysis of the soil.

The soil of the experimental area was classified as eutrophic yellow argisol with sandy texture (EMBRAPA, 2006). This was previously
GAMA et al.

characterized for its chemical characteristcs, presenting the following results: $\mathrm{P}=51,43 \mathrm{mg} \mathrm{dm}^{-3}$; $\mathrm{K}=1,30 \mathrm{cmol}_{\mathrm{c}} \mathrm{dm}^{-3} ; \mathrm{Ca}=0,70 \mathrm{cmol}_{\mathrm{c}} \mathrm{dm}^{-3} ; \mathrm{Mg}=$ $0,40 \mathrm{cmol}_{\mathrm{c}} \mathrm{dm}^{-3} ; \mathrm{H}+\mathrm{Al}=2,24 \mathrm{cmol}_{\mathrm{c}} \mathrm{dm}^{-3} ; \mathrm{CTC}$ efetiva $=4,73 \mathrm{cmol}_{\mathrm{c}} \mathrm{dm}^{-3} ; \mathrm{V} \%=52,64 ; \mathrm{pH}$ em água $(1: 2,5)=6,78 ; \mathrm{B}=0,90 \mathrm{mg} \mathrm{dm}^{-3} ; \mathrm{Cu}=0,80 \mathrm{mg} \mathrm{dm}^{-3}$; $\mathrm{Fe}=14,90 \mathrm{mg} \mathrm{dm}^{-3} ; \mathrm{Mn}=41,30 \mathrm{mg} \mathrm{dm}^{-3} ; \mathrm{Zn}=3,50$ $\mathrm{mg} \mathrm{dm}{ }^{-3}$.

After preparation and fertilization, a dripping tube line was placed in the central part of each seed bed, with $0.40 \mathrm{~m}$ spacing between emitters, and a double-sided, silver/black plastic film was installed ("mulching"). Then were made holes, which comprised the dens, with $0.40 \mathrm{~m}$ spacing between plants and $1.40 \mathrm{~m}$ between rows; one seedling was transplanted to each den. Irrigation management was performed using the tensiometer method (20 cm depth).

Top-dressings were performed via fertigation every two days. Other farming practices and the application of agricultural defensive substances were performed according to crop needs. Plants were conducted with sprouting throughout their cycle, and only the main stems were left.

In each environment, an automatic meteorological station was installed for the monitoring of global solar radiation $\left(\mathrm{Rg}, \mathrm{MJ}^{-2} \mathrm{~m}^{-2}\right.$, temperature $\left(\mathrm{T},{ }^{\circ} \mathrm{C}\right)$, and air relative humidity $(\mathrm{RH}$, \%) during the tomato productive cycle, which extended from transplantation to harvest at 90 days.

For growth analysis, was used the destructive method, in which whole plants were collected throughout their growth up to 90 DAT. Sampling seasons were: $0,15,30,45,60,75$, and 90 DAT. One whole plant was harvested from each replicate, totaling four plants from each treatment, in each sampling season. After harvesting, all parts were weighed separately, and placed in a forced ventilation oven at $65^{\circ} \mathrm{C}$ until they reached constant weight. Leaf area was obtained by taking photographs of fresh leaves, and subsequently measuring leaf area using the Quant program v. 1.0.1 (image analysis software characterized by a selection of basic and advanced procedures for scientific applications).

Based on the traits evaluated using growth analysis, it was determined the physiological indices and their respective mathematic formulas, according to Cairo, Oliveira and Mesquita (2008), being: IAF= $\mathrm{AF} / \mathrm{S} ; \quad \mathrm{AFE}=\mathrm{AF} / \mathrm{MSf} ; \quad \mathrm{RPF}=\mathrm{MSf} / \mathrm{MST}$; $\mathrm{RAF}=\mathrm{AF} / \mathrm{MST} ; \mathrm{TCA}=\left(\mathrm{P}_{2}-\mathrm{P}_{1}\right) /\left(\mathrm{T}_{2}-\mathrm{T}_{1}\right) ; \mathrm{TCR}=\left(\mathrm{LNP}_{2}\right.$ $\left.-\mathrm{LNP}_{1}\right) /\left(\mathrm{T}_{2}-\mathrm{T}_{1}\right) ; \mathrm{TAL}=\left[\left(\mathrm{P}_{2}-\mathrm{P}_{1}\right) /\left(\mathrm{T}_{2}-\right.\right.$ $\left.\left.\left.\mathrm{T}_{1}\right)\right] \mathrm{x}\left[\mathrm{LnAF}_{1}-\mathrm{LNAF}_{2}\right) /\left(\mathrm{AF}_{2}-\mathrm{AF}_{1}\right)\right] ; \mathrm{TCC}=\mathrm{TAL} \mathrm{x}$ IAF. Where: $\mathrm{AF}=$ total leaf area; $\mathrm{S}=$ soil surface; $\mathrm{MSf}=$ leaf dry matter; MSf and MSt = leaf and total 
dry matter; $\mathrm{P}_{1}$ and $\mathrm{P}_{2}=$ dry matter weight of two successive samplings; $\mathrm{T}_{1}$ and $\mathrm{T}_{2}=$ sampling time; $\mathrm{Ln}=$ neperian logarithm

Experiment results were submitted to variance analysis, and when they were significant, their means were compared using Tukey's test with $\mathrm{p}>0,05$ for factors environment and cultivar, and a regression analysis for the factor sampling seasons, using SISVAR Software.

\section{RESULTS AND DISCUSSION}

Global solar radiation transmittance of the different environments tested had the following values: the highest value was observed in the environment covered with red shading screen $(88.8 \%)$, followed by the environments covered with blue shading screen $(74.2 \%)$ and gray shading screen, with $52.9 \%$. While global solar radiation under open sun reached a total of $1342.5{\mathrm{MJ} . \mathrm{m}^{-2}}^{-2}$ during the experiment, it reached 1192.8 MJ.m $^{-2}$ under red shading screen, 996.1 MJ.m² under blue shading screen, and $699.7{\mathrm{MJ} . \mathrm{m}^{-2}}^{-2}$ under gray shading screen. It was also observed that open sun environment and the other shaded environments had the following mean daily values: open sun (16.6

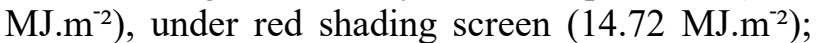

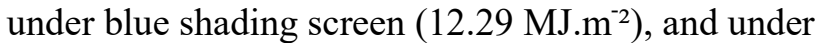
gray shading screen (8.63 MJ.m²) (Table 1).

Table 1. Global solar radiation transmittance, average values of maximum, mean, and minimum air temperature, global solar radiation $(\mathrm{Rg})$, global daily solar radiation (daily $\mathrm{Rg}$ ), and relative air humidity $(\mathrm{RH})$ in different types of cultivation environments.

\begin{tabular}{llccc}
\hline & \multicolumn{2}{c}{ Environments } & & \\
\cline { 2 - 5 } & Open sun & Red shading screen & Blue shading screen & Gray shading screen \\
\hline Transmittance $(\%)$ & 100.0 & 88.8 & 74.2 & 52.9 \\
Maximum Temp. $\left({ }^{\circ} \mathrm{C}\right)$ & 35.5 & 35.8 & 35.4 & 35.4 \\
Mean Temp. $\left({ }^{\circ} \mathrm{C}\right)$ & 25.9 & 26.2 & 25.8 & 25.8 \\
Minimum Temp. $\left({ }^{\circ} \mathrm{C}\right)$ & 16.5 & 16.8 & 16.4 & 16.4 \\
Rg $\left(\mathrm{MJ} . \mathrm{m}^{-2}\right)$ & 1342.5 & 1192.8 & 996.1 & 699.7 \\
Daily Rg $\left(\mathrm{MJ} . \mathrm{m}^{-2}\right)$ & 16.6 & 14.72 & 12.29 & 8.63 \\
Mean RH $(\%)$ & 66.4 & 66.0 & 65.8 & 64.3 \\
\hline
\end{tabular}

UNEB/DTCS. Juazeiro, BA.

There were no important differences in relative air humidity between environments; however, the environment under gray shading screen had the highest mean compared to the other environments. This might be related to the lower global solar radiation transmittance in this environment. Regarding temperature, there were no inportant variations in maximum, mean, and minimum temperatures between environments (Table I). According to Reis, Souza and Azevedo (2009), Oliveira et al. (2017), the cultivation of tomatoes in a protected environment has several advantages, among them, the reduction in the incidence of solar radiation, the wind speed and, consequently, the reduction of evapotranspiration. However, one of the factors that change most would be solar radiation, which is associated with surface water evaporation. This reduction was observed in the values presented in Table 1 , with reduction of global and daily solar radiation for all environments regarding the full sun cultivation.

Vegetable production in protected environment provides significant gains in productivity, improves the quality of fruits, facilitates treatment cultural rights, so the best use of water and minerals, which benefits the development of plants in relation to the crop field (MOREIRA et al., 2009).

According to FAO (2012), $8.4 \mathrm{MJ} \mathrm{m}^{-2}$ day $^{-1}$ is the value at which there is balance between photosynthetic absorption and oxidative release of $\mathrm{CO}_{2}$ in tomatoes. As shown in the table above, this reference value doubles in open sun cultivation and decreases with the presence of shading screens, equaling the reference value in the environment under gray shading screen.

According to Andriolo et al. (2004), among the factors that might influence dry matter accumulation and partitioning between the organs of the aerial part, the following are highlights: solar radiation intercepted by the crop, temperature, crop density, nutrient availability, and genotype.

There is little information on the growth of plants belonging to this tomato segment, called mini tomatoes. It is worth noting that according to Alvarenga (2013) there is a variety of mini tomatoes, including cherry tomato (round or piriform shape), "grape" tomato (grape/elongated shape), cocktail, mini Italian, and "tomato berry" 
(strawberry shape). In our study, we evaluated cherry tomato and "grape" tomato cultivars.

Thus, the climatic conditions of the study site, together with the physiological and morphological characteristics of the crop, are of great importance for understanding its growth and yield.

There was a significant interaction between cultivars and sampling seasons as to absolute growth rate (AGR), which had a quadratic behavior, reaching maximum growth at 60 DAT, with 4.98,

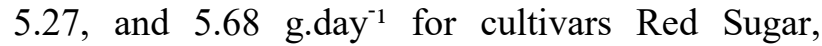
Shani, and Sweet Million, respectively. After that, AGR started to decrease up to the last sampling season (Figure 1 A). Soares et al. (2013), evaluating the AGR in tomato plants cultivated in soil protected with TNT verified the same behavior of values reduction, however after 84 DAT, with values higher than those observed in the present study.

The interaction of relative growth rate (RGR) between cultivars and sampling seasons was significant. Cultivars had a similar behavior with increasing rates up to $30 \mathrm{DAT}$; after that, these decreased up to the last sampling season (Figure 1 $\mathrm{B})$. This decrease is attributed to the decline both in net assimilation rate (NAR) and leaf area ratio (LAR).
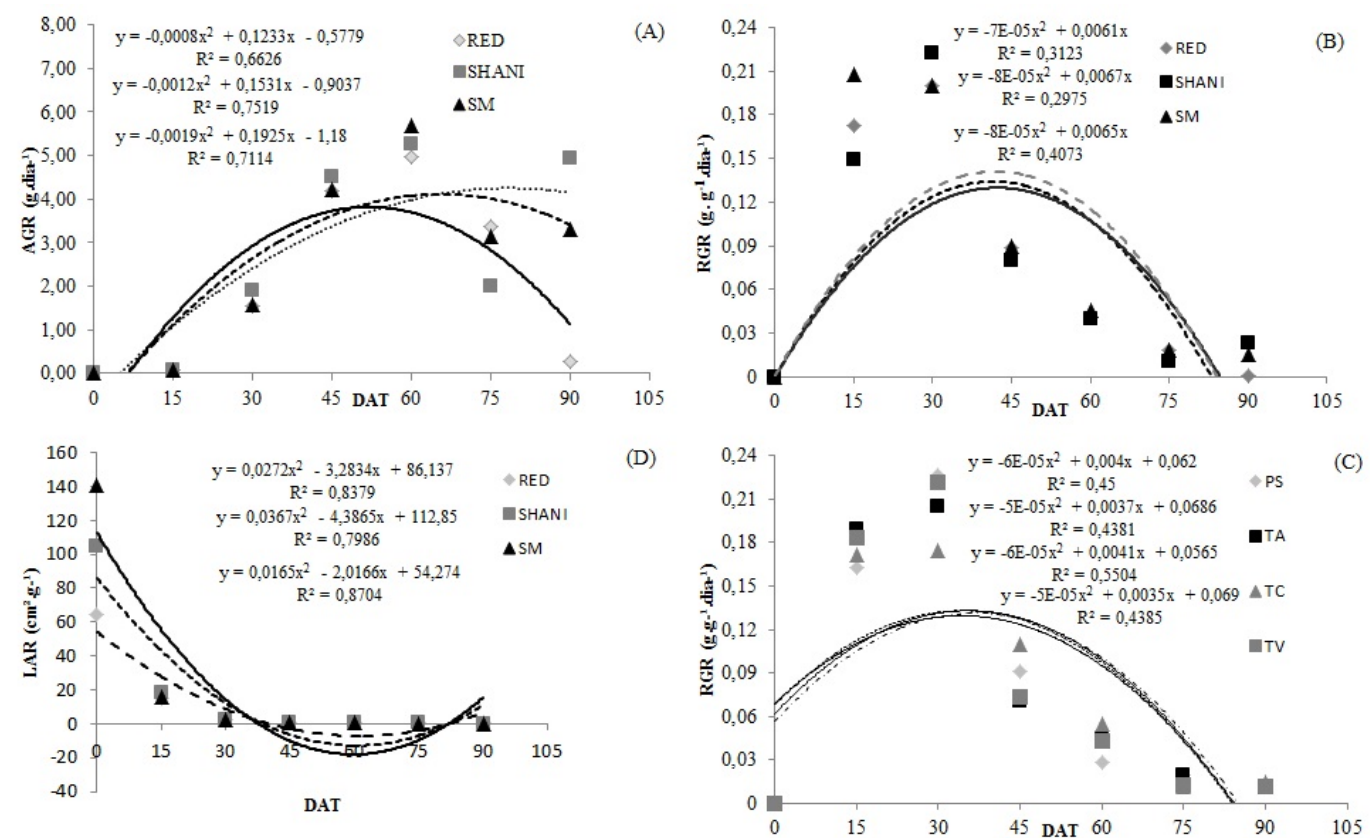

Figure 1. A) Absolute growth rate (AGR), B) relative growth rate (RGR) and D) leaf area ratio (LAR) of three mini tomato cultivars (RED- Red Sugar, SHANI, and SM- Sweet Million), grown in different types of environments C) relative growth rate (RGR) in different environments (OS - open sun, BS - blue shading screen, RS - red shading screen, and GS - gray shading screen). UNEB/DTCS. Juazeiro, BA.

Fayad et al. (2001) observed that absolute growth rate of field grown tomato cv. Santa Clara increased up to 45 DAT, decreasing from then onwards. In an experiment with protected grown of tomato hybrid "EF-50", Fayad et al. (2001) obtained maximum AGR at 75 DAT, reaching 5.7 g.day ${ }^{-1}$. AGR represents the plant's growth rate, and it grows as leaf area increases up to the moment when selfshading by leaves causes it to decline. According to Soares et al. (2013), evaluating the growth of hybrid tomato hybrid'SM-16' cultivated under soil cover with TNT, also observed a decrease in AGR values after 14 DAT, with values similar to those shown in Figure $1 \mathrm{~B}$.

According to Cairo, Oliveira and Mesquita (2008), the fact that existing values are not taken into consideration makes AGR a very limited parameter for growth analysis; it only works as a growth rate indicator. Soares et al. (2011), obtained AGR taking into consideration the plant height of 0.8 g.day ${ }^{-1}$ for tomatoes in a greenhouse.

In the interaction between environments and sampling seasons, we observed that the environments had a similar behavior; with increase in RGR up to 30 DAT, and a sharp decrease from 30 to 90 DAT (Figure I C). There was a significant interaction between cultivars and sampling seasons regarding leaf area ratio (LAR). Cultivars were similar in all sampling seasons, corroborating the decreasing quadratic behavior from transplantation up to 90 DAT (Figure I D). From 45 DAT onwards, when fruit set started, LAR values were the lowest. 
The leaf area ratio decreased throughout the crop cycle, with the maximum value at 27 DAT with an average of $201.5 \mathrm{~cm}^{2} \mathrm{~g}^{-1}$ and the minimum value at 112 DAT with $60.33 \mathrm{~cm}^{2} \mathrm{~g}^{-1}$. The behavior was similar to the observed in this study, however, with higher values. It is important to observe that in this case the plant was not covered, but the soil was covered with TNT.

Lopes et al. (2011), in an experiment with tomatoes in different soil covers, observed an increase in RGR up to 31 DAT; this was due to the increase in net assimilation rate, and its reduction was due to the continuous decrease in leaf area ratio and subsequent decrease in net assimilation rate. Fayad et al. (2001) cultivating tomato cv. Santa Clara, also observed that there was reduction in RGR throughout the crop cycle.
Testing two tomato hybrids (C-5240; D$4768)$ in different types of shaded environments and in open sun, Rocha et al. (2015), observed that there was no difference between environments; RGR increased up to 21 DAT, and values decreased after that until they reached a minimum value at 94 DAT.

Comparing the different environments regardless of the cultivars analyzed, there was a significant difference; the environment with gray shading screen stood out with the highest mean LAR, $18.34 \mathrm{~cm}^{2} \cdot \mathrm{g}^{-1}$ (Figure 2) and as observed previously, this environment had the lowest global solar radiation value (Table 1), which might have contributed to a higher leaf expansion in search for a higher solar light capture.

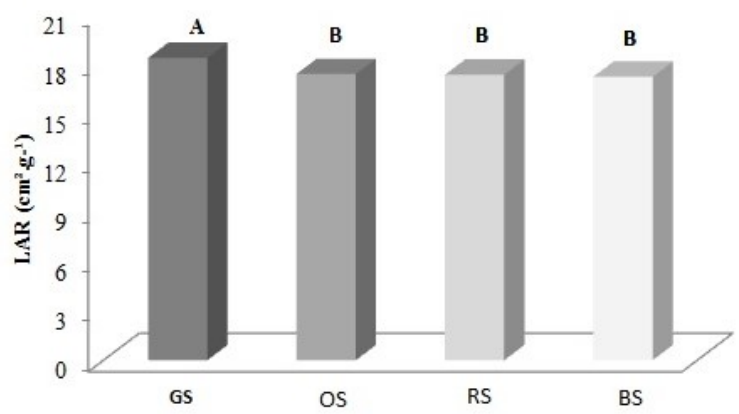

Figure 2. Leaf area ratio (LAR) of mini tomato cultivars grown in different types of environments (GS - gray shading screen, OS - open sun, RS - red shading screen, and BS - blue shading screen). UNEB/DTCS. Juazeiro, BA.

According to Lopes et al. (2011), this decrease indicates that the amount of assimilates destined to leaves progressively decreases as support and reproductive structures develop, to the detriment of investment in leaf area. Lopes et al. (2011), working with tomato in different soil covers, observed a decreasing LAR behavior up to 98 DAT.

Decrease in LAR indicates decrease in the amount of assimilates destined to the leaves, and it might cause reduction in RGR (SILVA et al., 2010; PEDÓ et al., 2013; FONTES; DIAS; SILVA, 2005). Cairo, Oliveira and Mesquita (2008) observed that it is understandable that LAR decreases as the plant grows because the influence of upper leaves on the lower leaves increases, causing self-shading.

Cultivars and sampling seasons had a significant interaction regarding leaf weight ratio (LWR). Comparing only environments (Figure $3 \mathrm{~A}$ ), there was a significant difference; the environment protected with red shading screen obtained the highest LWR. However, differences in LWR only occurred between open sun environment and the environment under red shading screen. This higher
LWR in the environment under red screen might be attributed to the higher dry matter accumulation in leaves in this environment, since LWR is the relationship between total leaf weight and whole plant weight; i.e., the higher the dry matter accumulation in leaves, the higher the LWR.

LWR was similar in all cultivars, with a decreasing quadratic behavior from 15 DAT up to the last sampling season (Figure $3 \mathrm{~B}$ ). Up to 30 DAT, there was a slow decrease in LWR, and from then onwards, it became more pronounced up to 90 DAT.

Rocha et al. (2015), observed that up to approximately $30 \mathrm{DAT}$, LWR kept increasing and it had practically the same levels between the two hybrids; after that, it decreased due to the redistribution of compounds photosynthesized by the plant. This means that the fraction of photoassimilates retained in the leaf becomes smaller as the plant grows, i.e., exportation to other plant organs becomes higher (CAIRO; OLIVEIRA; MESQUITA, 2008). 

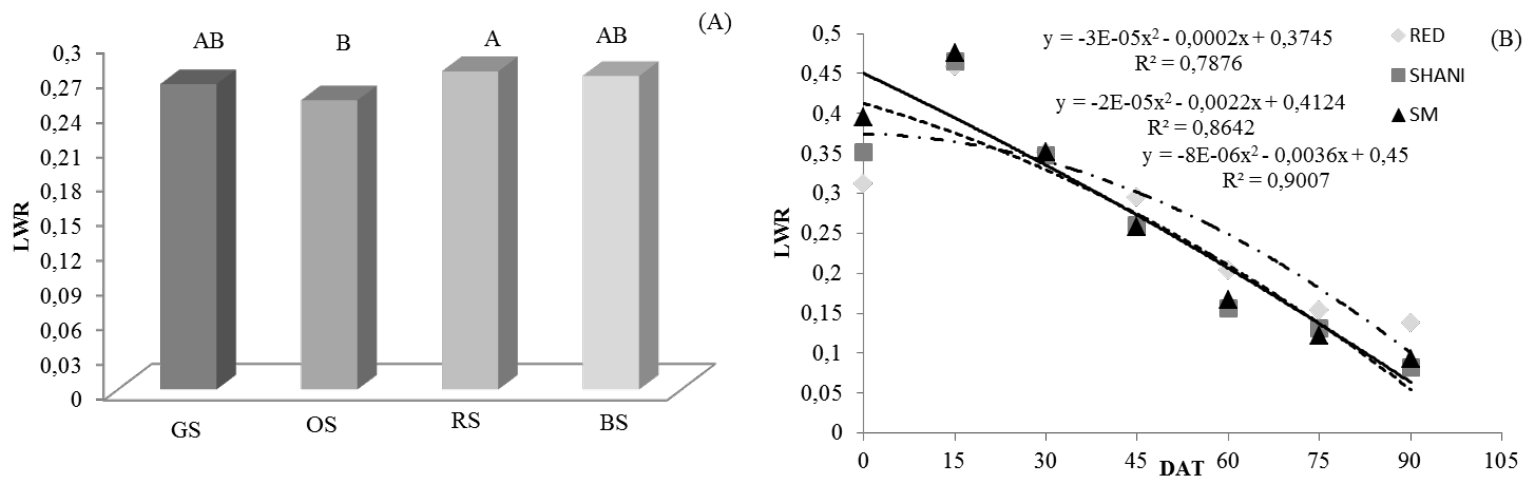

Figure 3. A) Leaf weight ratio (LWR) independent cultivars grown in different types of environments and B) Leaf weight ratio (LWR) of three mini tomato cultivars grown in different types of environments (GS - gray shading screen, OS - open sun, RS - red shading screen, and BS - blue shading screen). UNEB/DTCS. Juazeiro, BA.

The interaction was significant only for cultivars and sampling seasons regarding specific leaf area (SLA), which had a quadratic behavior (Figure 4 B). Maximum SLA values estimated for cultivars Red Sugar, Shani, and Sweet Million occurred on transplantation day with 198.17, 298.05, and $351.76 \mathrm{~cm}^{2} \cdot \mathrm{g}^{-1}$, and from this date onwards, SLA decreased up to the end of the evaluation period, at 90 DAT. This decrease in SLA indicates there was increase in leaf biomass and decrease in leaf expansion (LOPES et al. 2011). Specific leaf area (SLA) is related to leaf thickness or to leaf density and is closely linked to bright environments. However, no interaction between cultivars and environments was observed.
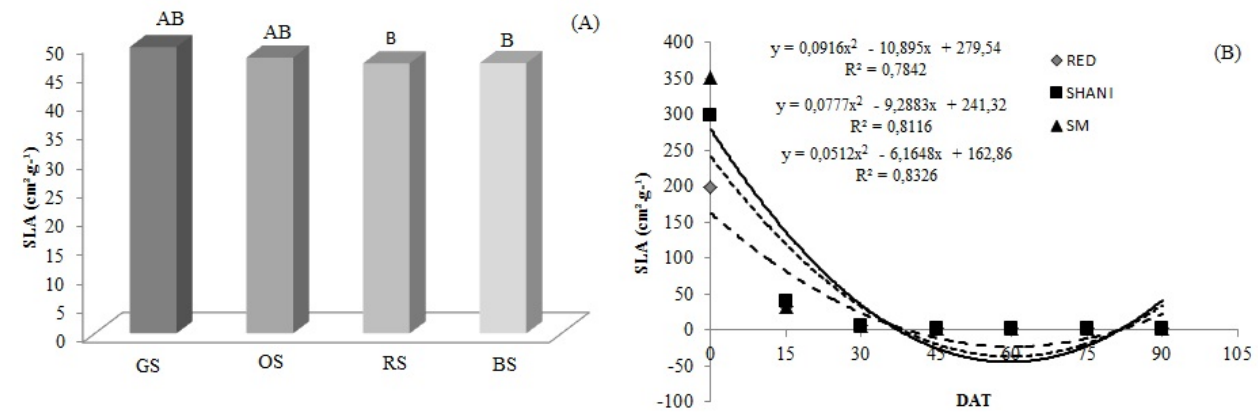

Figure 4. A) Specific leaf area (SLA) in terms of the different types of environment and B) Specific leaf area (SLA) of three mini tomato cultivars (RED- Red Sugar, SHANI, and SM- Sweet Million) in terms of sampling seasons. UNEB/DTCS. Juazeiro, BA.

There were statistical differences with $5 \%$ of probability in the factor environment, and plants in the environment under gray shading screen obtained the highest specific leaf area, with 49.46 $\mathrm{cm}^{2} \cdot \mathrm{g}^{-1}$. On the other hand, there was no difference between open sun and protected environments.

Similar results were observed by Fayad et al. (2001), working with tomato hybrid EF-50 in a protected environment. They observed that SLA increased up to 30 days after transplantation; it started decreasing soon after, and continued to decrease until the end of the experiment. Heuvelink (1995) also found a similar behavior when working with tomato cv. Counter in greenhouse.
Leaf area index (LAI) is the relationship between leaf area and the soil area shaded by leaves. The leaf area of a plant constitutes an important factor for photosynthesis, and as such is essential in the production of carbohydrates, lipids, and proteins. There was a triple significant interaction between environments, cultivars, and sampling seasons for leaf area index (LAI); while monitoring tomato development, we observed that cultivars in the open sun environment had similar indices throughout all sampling seasons, with the highest leaf area indices at $60 \mathrm{DAT}$, and a trend towards stabilizing from then onwards (Table 2 ). 
Table 2. Mean values of leaf area index of three cultivars of mini-tomatoes (RED - Red Sugar, SHANI, and SM - Sweet Million) cultivated in different types of environments. LAI - LEAF AREA INDEX

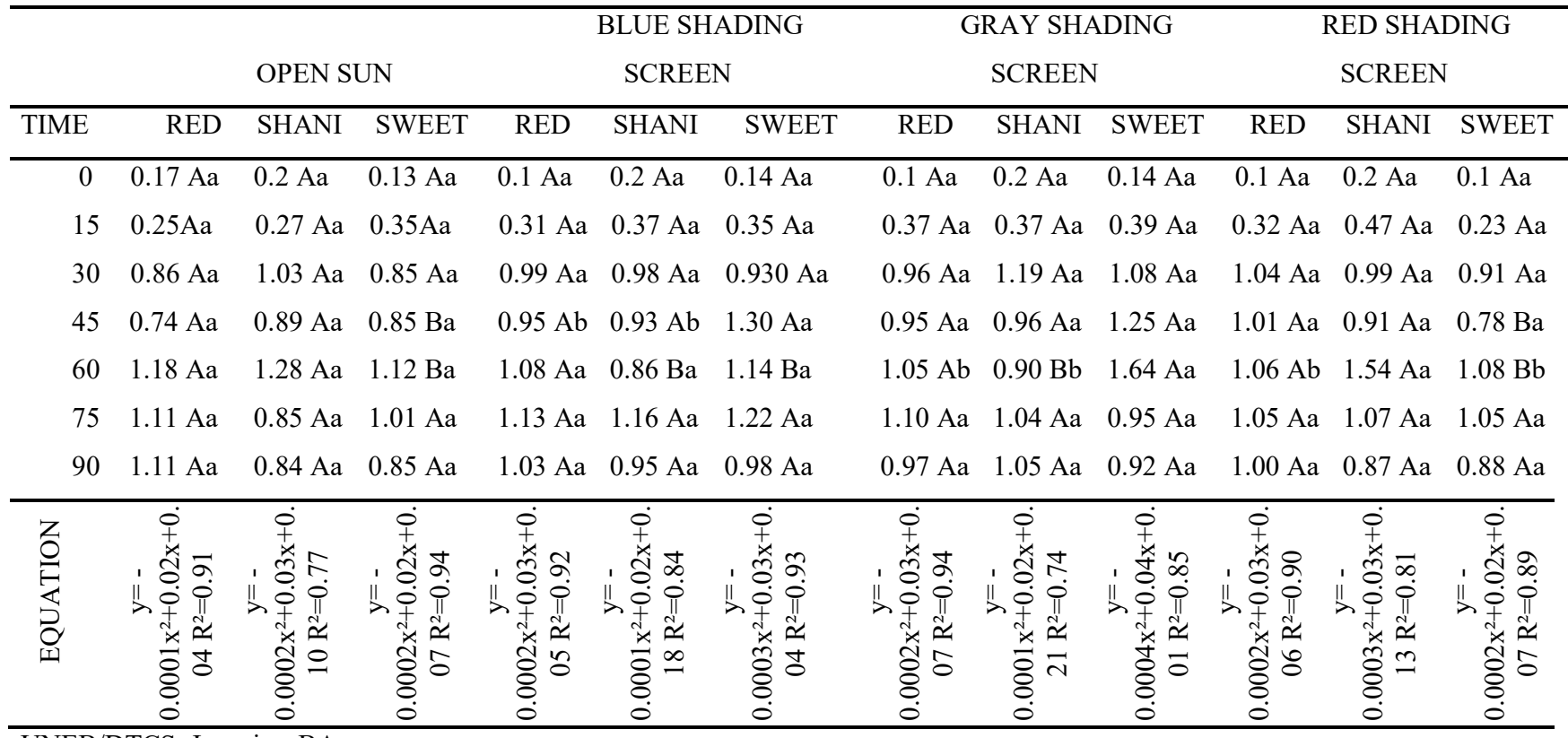

UNEB/DTCS. Juazeiro, BA.

*Means followed by the same lowercase letter in the column and uppercase letter in the row for each do not differ statistically using Tukey's test with $p \leq 0,05$ probability. Regression analysis equations are in the lower part of the table.

In the environment with blue shading screen, the cultivars had similar indices up to 30 DAT, and from 45 DAT onwards, cultivar Sweet Million (SM) stood out with the maximum value (1.305) and the highest indices, whereas cultivars Red Sugar and Shani obtained the highest indices at 75 DAT; 1.137 and 1.162, respectively.

In the environment covered with gray shading screen, the cultivars had similar indices up to 45 DAT; cultivar Sweet Million obtained the highest indices and maximum index (1.647) at 60 DAT while the other cultivars obtained the highest indices at 75 DAT.

Cultivars had similar indices up to 45 DAT in the environment with red shading screen, and they obtained the highest leaf area indices at 60 DAT; cultivar Shani obtained the highest index (1.545) compared to the other cultivars.

When each cultivar was compared between environments, Red Sugar obtained similar leaf area indices in all sampling seasons, reaching the highest indices at 60 DAT in the open sun environment and under red shading screen and at 75 DAT in the environments with blue and gray shading screens. Shani had similar values up to 45 DAT, and from then onwards, leaf area indices were distinct; open sun environment and the environment under red shading screen had the highest indices, 1.282 and 1.545 , respectively. On the other hand, Sweet Million showed similar indices up to 30 DAT, and after that, it had distinct values between environments in the sampling seasons. In the environments in open sun, under gray shading screen, and under red shading screen, the highest indices were attained at 60 DAT, whereas the highest index in the environment with blue shading screen was attained at 45 DAT.

Cultivars showed quadratic significance in the environments throughout the days assessed, with a similar behavior for all cultivars regarding leaf area index (LAI). Corroborating the results found by Rocha et al. (2015), who worked with tomato under different types of shading screens, we observed a more rapid LAI growth in the cultivars from 30 to 60 DAT, with a trend towards stabilization at 75 DAT, and a drop in leaf area index from 90 DAT onwards, indicating senescence and leaf abscission. In an experiment with protected grown tomato hybrid EF-50, Fayad et al. (2001) observed that LAI increased up to 93 DAT, with a trend towards stabilizing after that; this behavior was similar to the one found in our experiment.

There was a significant interaction between cultivars and sampling seasons regarding net assimilation rate (NAR). Cultivars had a similar, increasing behavior up to $60 \mathrm{DAT}$, and from then onwards, NAR of Red Sugar and Sweet Million started to decrease, while NAR of Shani started to decrease at 75 DAT. There was no significant 
difference between environments as to net assimilation rate (NAR).

This decrease is attributed to the increase in plant growth, including leaf area, which causes selfshading by the leaves, and consequently, decreased net photosynthesis or NAR. Farming practices, varieties, types of growth habits might influence the tomato's NAR behavior.

Fayad et al. (2001), working with tomato cv. Santa Clara, indeterminate in growth, observed that NAR increased up to 45 DAT, decreasing from then onwards. In an experiment conducted with tomato in different types of soil covers, Lopes et al. (2011) observed that net assimilation rates increased up to 28 DAT, decreasing as the plant aged from 28 DAT onwards, since plant growth (including leaf area) causes self-shading by leaves, which leads to the decrease in the levels of net photosynthesis, or NAR. Soares et al. (2013), reports that NAR decreased linearly after 14 DAT in tomato hybrids grown in mulch.

According to Cairo, Oliveira and Mesquita (2008), these leaf area indices (LAI) are called optimal LAI, and they vary according to species and growth stage.

There was a significant interaction between cultivars and sampling seasons regarding crop growth rate (CGR) (Figure 5). Cultivars had a similar, quadratic behavior up to 60 DAT. From 60 DAT onwards, CGR of cultivars Red Sugar and Sweet Million started to decrease, while CGR of Shani started to decrease at 90 DAT.

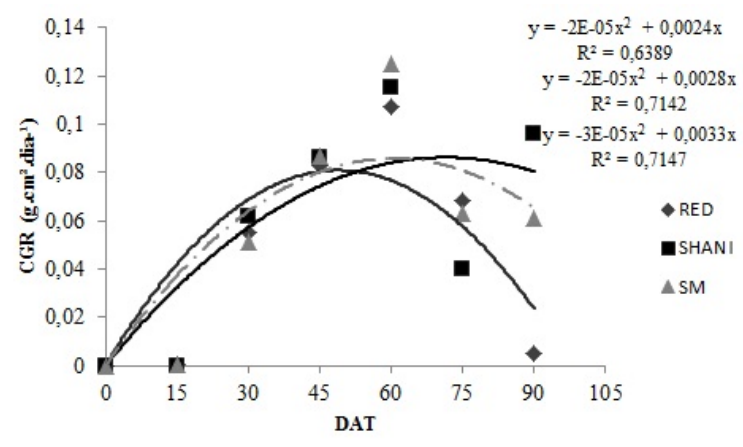

Figure 5. Crop growth rate (CGR) of three mini tomato cultivars (RED- Red Sugar, SHANI, and SM- Sweet Million) in terms of sampling seasons. UNEB/DTCS. Juazeiro, BA.

The highest CGR values were obtained between 45 and 75 DAT, when LAI was intermediate. In terms of all variables analyzed and described previously, we might infer that the higher the LAR and LAI values, the higher the CGR, and cultivars Shani and Sweet Million had the highest CGR, which may provide increased on number of fruits and yield.

CGR values increase until the plant's upper leaves start to cause self-shading on the lower leaves, and from this moment onwards, CGR starts to be affected by the limited ability of intercepting light radiation. Self-shading causes the following indices to decrease: absolute growth rate, relative growth rate, leaf area ratio, leaf area index, and net assimilation rate. Consequently, crop growth rate also starts to decrease.

\section{CONCLUSIONS}

Environment influenced leaf area index of the cultivars evaluated, except for Red Sugar, which kept a constant index, showing adaptability to environments.

This cultivar showed the lowest leaf area index, and consequently, the lowest specific leaf area and leaf area ratio. On the other hand, it showed the highest leaf weight ratio, since it obtained the highest dry matter in leaves compared to the other cultivars.

Cultivars Shani and Sweet Million showed the best net assimilation, relative growth, absolute growth, and crop growth rates.

RESUMO: As telas de sombreamento são utilizadas para controlar a radiação solar excessiva, podendo alterar o crescimento das plantas. Desse modo, objetivou-se por meio de índices fisiológicos avaliar o crescimento de três cultivares de mini tomates sob malhas coloridas. $\mathrm{O}$ experimento foi conduzido no período de abril a julho no campo experimental do DTCS/UNEB em delineamento experimental DBC, com parcelas subsubdivididas, com quatro repetições, compostos de três ambientes sombreados além do controle, três 
cultivares e sete épocas de amostragens. Para análise de crescimento, utilizou-se o método destrutivo e as massas secas totais obtidas após secagem em estufa a $65^{\circ} \mathrm{C}$. A área foliar total foi obtida usando-se o software QUANT. Os resultados mostraram que não houve interação entre os ambientes e os demais fatores. Quanto as cvs., para índice de área foliar (LAI), destacaram-se as cvs. Shani e Sweet Million dentro de cada ambiente, tendo a cultivar Red Sugar comportamento similar nos ambientes. A cv. Shani obteve os melhores índices no ambiente a céu aberto e com tela vermelha e a cv. Sweet Million o melhor índice na tela cinza. A cv. Red Sugar apresentou o menor LAI, e consequentemente à menor AFE e RAF, em contrapartida apresentou a maior RPF, uma vez que obteve a maior massa seca nas folhas quando comparada as outras cultivares. As cvs. Shani e Sweet Million apresentaram as melhores: TAL, TCR, TCA e TCC.

PALAVRAS-CHAVE: Telas de sombreamento. Área foliar. Taxa de crescimento.

\section{REFERENCES}

ANDRIOLO, J. L.; ESPINDOLA, M. C. G.; GODOI, R.; BORTOLOTTO, O. C.; LUZ, G. L. Crescimento e produtividade de plantas de tomateiro em cultivo protegido sob alta densidade e desfolhamento. Ciência Rural, v.34, p.1251-1253, 2004. https://doi.org/10.1590/S0103-84782004000400047

ALVARENGA, M. A. R. Tomate: produção em campo, casa-de-vegetação e hidroponia. $2^{\text {a }}$ Ed. Lavras: UFLA. 2013.455p.

BUTHELEZI, M. N. D. et al. Spectral quality of photoselective nets improves phytochemicals and aroma volatiles in coriander leaves (Coriandrum sativum L.) after postharvest storage. Journal of Photochemistry and Photobiology Biology, V.161, p.328-334, 2016. https://doi.org/10.1016/j.jphotobiol.2016.05.032

CAIRO, P. A. R.; OLIVEIRA, L. E. M.; MESQUITA, A. C. Análise de crescimento de plantas. Vitória da Conquista: Edições UESB, 2008. 71p.

COSTA, N. D.; FARIA, C. M. B.de; PEREIRA, J. R. Tomate rasteiro irrigado. In. CAVALCANTE, F.J.de.A. (coord.) Recomendações de adubação para o estado de Pernambuco: $2^{\mathrm{a}}$ aproximação. Recife: IPA, $2008.195 \mathrm{p}$.

FAO. (2012). Faostat Disponível em: <Disponível em:

http://www.faostat3.fao.org/home/index.html\#DOWNLOAD >. Acessado em: 20 de fevereiro de 2013.

FAYAD, J. A.; FONTES, P. C. R.; CARDOSO, A. A.; FINGER, F. L.; FERREIRA, F. A. (2001). Crescimento e produção do tomateiro cultivado sob condições de campo e de ambiente protegido. Horticultura Brasileira, v. 19, n. 3, p.15-19, 2001. https://doi.org/10.1590/S0102-05362001000300016

FONTES, P. C. R.; DIAS, E. N.; SILVA, D. J. H. da. Dinâmica do crescimento, distribuição de matéria seca e produção de pimentão em ambiente protegido. Horticultura Brasileira, Brasília, v. 23, n. 1, p. 94-99, 2005. https://doi.org/10.1590/S0102-05362005000100020

GAMA, D. R. S.; MESQUITA, A. C.; YURI, J. E.; SOARES, K. M.; SOUZA, V. Different shading environments impact growth and yield of three mini-tomato cultivars. Revista Caatinga, v. 30, n. 2 , p. $324-$ 334, 2017. https://doi.org/10.1590/1983-21252017v30n207rc

HOLCMAN, E.; SENTELHAS, P. C. Microclimate under different shading screens in greenhouses cultivated with bromeliads. Revista Brasileira de Engenharia Agrícola e Ambiental, Campina Grande, v. 16, n. 8, p. 858-863, 2012. https://doi.org/10.1590/S1415-43662012000800007

IBGE - INSTITUTO BRASILEIRO DE GEOGRAFIA E ESTATÍSTICA. Levantamento sistemático da produção agrícola. Rio de Janeiro. 2019. 
ILIĆ, Z. S.; FALLIK, E. Light quality manipulation improves vegetable quality at harvest and postharvest: A review. Environmental and Experimental Botany, v. 139, p. 79-90, 2017.

https://doi.org/10.1016/j.envexpbot.2017.04.006

LOPES, W. A. R.; NEGREIROS, M. Z.; DOMBROSKI, J. L. D.; RODRIGUES, G. S. O.; SOARES, A. M.; ARAÚJO, A. P. Análise do crescimento de tomate 'SM-16' cultivado sob diferentes coberturas de solo.

Horticultura Brasileira, v. 29, p. 554-561, 2011. https://doi.org/10.1590/S0102-05362011000400019

MARTÍNEZ-GUTIÉRREZ, G. A. et al. Growth and oil content of basil (Ocimum basilicum L.) grown under colored shade nets. Interciencia, v., n. 6, p.428-432, 2016.

MOREIRA, S. O.; RODRIGUES, R.; ARAÚJO, M. L.; SUDRÉ, C. P.; RIVA-SOUZA, E. M. Desempenho agronômico de linhas endogâmicas recombinadas de pimenta em dois sistemas de cultivo. Ciência Rural, Santa Maria, v. 39, n. 5, p. 1387-1393, 2009. https://doi.org/10.1590/S0103-84782009005000080

OLIVEIRA, G. M.; SANTIAGO, E. J. P.; LEITÃO, M. M. V. B. R.; ROCHA, R. C.; GONÇALVES, I. S.; SILVA, R. R. Estimativa da evapotranspiração de referência para ambiente protegido. Irriga, Edição Especial, Irriga \& Inovagri, p.21-30, 2017. https://doi.org/10.15809/irriga.2017v1n1p21-30

PEDÓ, T.; AUMONDE, T. Z.; LOPES, N. F.; VILLELA, F. A.; MAUCH, C. R. Análise comparativa de crescimento entre genótipos de pimenta cultivados em casa de vegetação. Bioscience Journal, Uberlândia, v. 29 , n. 1, p. 125-131, 2013.

REIS, L. S.; SOUZA, J. L.; AZEVEDO, C. A. A. V. Evapotranspiração e coeficiente de cultivo do tomate caqui cultivado em ambiente protegido. Revista Brasileira de Engenharia Agricola e Ambiental - v.13, n.3, p.289-296, 2009. https://doi.org/10.1590/S1415-43662009000300010

REIS, L. S.; SOUZA, J. L. de; AZEVEDO, C. A. V. de; LYRA, G. B.; FERREIRA JUNIOR, R. A.; LIMA, V. L. A. de. Componentes da radiação solar em cultivo de tomate sob condições de ambiente protegido. Revista Brasileira Engenharia Agrícola e Ambiental, Campina Grande, PB, v. 16, n. 17, p. 739-744, 2012. https://doi.org/10.1590/S1415-43662012000700006

REIS, L. S.; AZEVEDO, C. A. V.; ALBUQUERQUE, A. W.; JUNIOR, J. F. S. Indice de área foliar e produtividade do tomate sob condições de ambiente protegido. Revista Brasileira de Engenharia Agrícola e Ambiental, v.17, n.4, p.386-391, 2013. https://doi.org/10.1590/S1415-43662013000400005

ROCHA, R. C.; CAMPOS, C. O.; OLIVEIRA, G. M. R.; GOTO, R.; LEITÃO, M. M. V. B. R.; VIEIRA, J. P. S.; SILVA, L. B.; CARVALHO, T. G. Características de crescimento de híbridos de tomateiro em ambiente protegido e a campo aberto na região do Submédio São Francisco. Revista SODEBRAS - v. 10 n.112, p. 110$116,2015$.

SHAHAK, Y.; GUSSAKOVSKY, E.; GAL, E. ColorNets: crop protection and light-quality manipulation in one technology. Acta Horticulturae, n.659, p.143-151, 2004. https://doi.org/10.17660/ActaHortic.2004.659.17

SHAHAK, Y.; GAL, E.; OFFIR, Y.; BEN-YAKIR, D. Photoselective shade netting integrated with greenhouse technologies for improved performance of vegetable and ornamental crops. Acta Horticulturae, n.797, p.7580, 2008. https://doi.org/10.17660/ActaHortic.2008.797.8

SILVA, P. I. B.; NEGREIROS, M. Z.; MOURA, K. K. C. F.; FREITAS, F. C. L.; NUNES, G. H. S.; SILVA, P. S. L.; GRANGEIRO, L. C. Crescimento de pimentão em diferentes arranjos espaciais. Pesquisa Agropecuária Brasileira, Brasília, v. 45, n. 2, p. 132-139, 2010. https://doi.org/10.1590/S0100204X2010000200003 
Physiological indexes...

GAMA et al.

SILVA, C. R.; VASCONCELOS, C. S.; SILVA, V. J.; SOUSA, L. B.; SANCHES, M. C. Crescimento de mudas de tomateiro com diferentes telas de sombreamento. Bioscience Journal, v.29, supplement 1. p. 14151420, 2013.

SOARES, L. A. A.; LIMA, G. S.; BRITO, M. E. B.; ARAÚJO, T. T.; SÁ, F. V. S. Taxas de crescimento do tomateiro sob lâminas de irrigação em ambiente protegido. Revista Verde, Mossoró, RN, v.6, n.2, p.210 217, 2011.

SOARES, A. M.; NEGREIROS, M. Z.; LOPES, W. A. R.; DOMBROSKI, J. L. D.; LUCENA, R. R. M. Crescimento do tomateiro cultivado em solo coberto com polipropileno Preto. Revista Ciência Agronômica, v. 44, n. 4, p. 790-797, 2013. https://doi.org/10.1590/S1806-66902013000400016

TAFOYA, F. A.; JUAREZ, M. G. Y.; ORONA, C. A. L.; LOPEZ, R. M.; ALCARAZ, T. J. V.; VALDES, T. D. Sunlight transmitted by colored shade nets on photosynthesis and yield of cucumber. Ciência Rural, v.48, n.09, e20170829, 2018. https://doi.org/10.1590/0103-8478cr20170829 